\title{
Economic analysis of goat rearing in Amravati district
}

\author{
P.S. CHAVAN, A.S. KHOSE AND B.G. NAIR
}

\begin{abstract}
The findings of the study reveal that the small, medium, large goat rearers and goat farms with average herd size (including below and above one year) 13.71, 21.28, 34.21, 73.30, respectively. Increase in stock at the end of the year was 14.21, $21.74,34.55,75.10$, respectively in case of small, medium, large categories of goat rearers and goat farms. Average total receipt was observed to be Rs. 33747.48, Rs. 66726.13, Rs. 118609.42 and Rs. 217917.00. Average total cost incurred was found to be Rs. 28094.76, Rs. 41816.50, Rs. 58966.38 and Rs. 146114.50, respectively towards small, medium, large goat rearers and goat farms. The average input-output was 1:1.20,1:1.60, 1:2.01 and 1:1.49, respectively towards small, medium, large goat rearers and goat farms.
\end{abstract}

KEY WORDS : Cost, Economics, Net income, Receipt

HOW TO CITE THIS PAPER : Chavan, P.S., Khose, A.S. and Nair, B.G. (2015). Economic analysis of goat rearing in Amravati district. Res. J. Animal Hus. \& Dairy Sci., 6(1) : 6-11. 